\title{
THE EFFECT OF COMPUTER TECHNOLOGIES ON THE PSYCHOLOGICAL DEVELOPMENT OF YOUNGER SCHOOL CHILDREN
}

\author{
ВПЛИВ КОМП'ЮТЕРНИХ ТЕХНОЛОГІЙ НА ПСИХОЛОГІЧНИЙ РОЗВИТОК \\ молОДШИХ ШКОЛЯРІВ
} The aim of the research is to identify the ways of
the use of effective means of communication to
provide young students with the necessary infor-
mation on specific subjects and topics through
computer technology.
The article discusses the learning technologies
used in early childhood and their impact on stu-
dents. A brief description of this research on the
problem shows that in order to use computer
technology in the learning process, teachers
must first have technological skills. At the same
time, the requirements for the application of
learning technologies must be observed. Com-
puters should be used effectively in the learn-
ing process, and students should be active.
Lessons conducted in such conditions create
significant changes in the psyche of students.
They increase the stability of attention, increase
motivation, regulate the emotional sphere, and
create ample opportunities for the development
of intellect.

This suggests that the technologies used in the learning activities of young students are not only a modern requirement for a more effective organization of their learning activities, but also a crucial learning tool. However, as with other visual aids, the necessary requirements for the preparation and placement of information must be met. Information should have a developmental, educational and pedagogical function for the cognitive activity of young students, both in terms of content and visuals.

Methods. The Phillips Anxiety Test and the Test Method for Determining the Level of Mental Development in Children of 7-10 Years of Life "Intellectual lability" test was applied, scientific observations were made, and conversations and discussions were held.

Results. The results showed that the information provided to young students in a convenient way through computer technology strengthens their emotional stability, attention and intelligence.

Suggestions. In order to increase the effectiveness of the use of computer technology in the educational activities of young students, first of all, teachers' ICT skills should be increased, students' knowledge and skills in computer science should be strengthened, and computer technology should become a key resource for the learning process.

Key words: teaching technologies, pedagogical technologies, academic assessment, mental development, intellectual lability, arousal, motivation.

Метою дослідження $є$ виявлення способів використання ефективних засобів впливу на передачу інфрормації молодшим школярам із конкретних предметів і темам за допомогою комп'ютерних технологій.

у статті розглядаються технології навчання, що використовуються в ранньому дитинстві, $і$ їх вплив на учнів. Короткий опис цього дослідження проблеми показує, що для використання комп'ютерних технологій в прочесі навчання вчителі повинні спочатку опанувати технологічні навички. Водночас повинні бути дотримані вимоги до застосування технологій навчання. Комп'ютери повинні есрективно використовуватися в прочесі навчання, а учні повинні бути активними. Уроки, проведені в таких умовах, створюють значні зміни в психіці учнів. Вони підвищують стабільність уваги, мотивацію, регулюють емоційну ссреру, створюють широкі можливості для розвитку інтелекту.

Це дає підставу сказати, що технології, які використовуються в навчальній діяльності молодших школярів, не тільки відповідають сучасним вимогам для більш ефективної організаціїї навчальної діяльності, ає також важливим інструментом навчання. Однак, як і в разі інших наочних посібників, під час підготовки та розміщення інфрормації повинні бути дотримані необхідні вимоги. Інфоормація повинна мати розвиваючу, освітню та педагогічну функцію для пізнавальної діяльності молодших школярів, як з погляду змісту, так і з погляду форми.

методи. Для визначення способів передачі інсрормації, пов'язаної з навчальними матеріалами для молодших школярів за допомогою комп'ютерних технологій, був застосований «тест збудження Філліпса», «методика визначення рівня психічного розвитку у дітей 7-10 років», «Інтелектуальна лабільність», проведені наукові спостереження, бесіди та дискусії.

Отримані результати. Результати показали, що інформація, яка надається молодшим школярам за допомогою комп'ютерних технологій, підвищує їх емоційну стабільність, увагу і інтелект.

Висновки. 3 метою підвищення ефективності використання комп'ютерних технологій в освітній діяльності молодших школярів передусім необхідно підвищити навички викладачів у ссрері IKT, зміцнити знання і навички учнів в сорері комп'ютерних наук, а комп'ютерні технології повинні стати основним ресурсом навчального процесу. Ключові слова: технології навчання, педагогічні технології, академічна оцінка, розумовий розвиток, інтелектуальна лабільність, порушення, мотивація.
Doctoral Candidate in the
of Ph. D. of Psychology

Azerbaijan State Pedagogical University
Formulation of the problem. There are a number of provisions in the science of psychology regarding the impact of computer technology used in the educational activities of young students. Researchers approach the issue in terms of new learning technologies. These approaches 
discuss the positive and negative effects of computer technology on the psyche of young schoolchildren, its developmental significance, as well as the problems it can create for children's health.

Statement of the task. The purpose of the article is to research the effect of computer technologies on the psychological development of younger school children.

Presentation of the main research material. In general, the psychological content of computer technology is related to the process of self-perception. Two more theses are put forward here. The most important of them is to increase the professionalism of teachers:

a) To convey to students the latest developments in the world, and various information continuously and effectively;

b) To create learning motivation in young schoolchildren, to acquaint them with the ways of self-activation;

c) To look for ways to better master the training materials;

d) To make suggestions to young students on how to solve tasks;

e) To be able to identify appropriate ways of development in their individuality.

A number of researchers are directly concerned with the importance of using new learning technologies. A.M. Nazarov - modern learning technologies (1), Z.A. Abasov - pedagogical technologies and innovations in the educational activities of schoolchildren (2), V.V. Art-Yomova didactic conditions for teaching young students about nature through computer technology (3), E.V. Utiski - studied the problem in the research on the application of computer technology in the education of young schoolchildren (4).

L.V. Sukhoyvanova includes the following functions in the teacher's work during the application of computer technology (9):

1. Organization of the educational process at the class level in general, and at the subject level as a whole (schedule of the educational process, external diagnostics, final control).

2. Organization of activation and coordination within the classroom (schedule of the learning process, external observation, management of intra-class relations, etc.).

3. Individual supervision of students, individual assistance, individual contact with the child. When using a computer, the teacher uses visual images, sound (music, text, etc.) to increase the level of learning and mastery of students.

4. While preparing components for the information environment (various types of training, demonstration equipment, programs and systems, teaching aids, etc.) they should be related to the specific topics to be taught to children.

There is a lot of research on the application of computer technology directly in the primary grades. Among them are: S.M. Selebeyeva and G.B. Pronchev on the use of computer technology in primary education (5), the impact of computerization on the formation of students' thinking in the educational activities of V.N. Mogiyova (6), E.V. Ogorodnikov's parallel in information technology. We studied the method of chronology (7), the role of I.M. Pavlova in the preparation of young schoolchildren for design activities (8) and other similar research works. Based on their research, we have developed a research methodology. Our experiments have shown that the use of various sources of information through computer technology in the primary grades of young students increases the effectiveness of training.

We started the final stage of the research in October-December of the 2019-2020 academic year. We continued our work in the teaching and formative stages. First, we conducted psycho-diagnostic work to determine the emotional and intellectual resilience and mental development of students. For this purpose, we used B. Phillips's "School Anxiety Test", "Test-methodology to determine the level of mental development in children aged 7-10", "Intelligence lability" modified for young schoolchildren (10).

We conducted an initial diagnosis in October, 2019. We organized classes for the 3rd and the 4th grade students. With the participation of an expert, we organized external lessons on various subjects and taught students the impact of computer technology.

Diagnosis of the motivation of learning activities and the level of mastery of topics showed that students are more interested in computer-based lessons. The use of computers at various stages of learning allows students to spend $75-80 \%$ of their study time for comprehension instead of $15-20 \%$. Inspection and control work on the environment shows positive dynamics of general awareness in the acquisition of knowledge. In the classroom where we conducted research on this subject, the mastery of learning materials ranged from 65 to $85 \%$. That is, the vast majority of students had academic grades in that subject at the level of 4-5. At the end of the study, this figure rose to $75-93 \%$.

We organized the initial diagnosis of the effectiveness of the use of computers in the lessons of the Azerbaijan language on the state of students' cognitive activity in these lessons. We followed the students' activities in the computer-based Mother Tongue classes. Their activity on the subject was clearly observed. If the students were not active in the traditional (declarative) lesson, if they were not seriously interested in the information provided by the teacher, in the computer-based lessons on this subject, they became more active and took an initiative in learning activities. They tried to take an active part in the discussion of the questions in the lesson, did not hesitate to express their opinions, easily worked in pairs and groups, shared the information they received 
with each other, and prepared joint answers. Even the noise in the classroom did not bother them and the observers. Even the most silent, indifferent, and stubborn students, who were not interested in working together, showed a desire to complete assignments together. In short, the experience has shown that the more active the cognitive process in young schoolchildren, the more productive the results is in that subject. Motivation of the topic in this area is the first and main, decisive step. This stage is more efficient when organized with the help of computer technology.

During the implementation of the program, it became clear that many students are more familiar with computer game technology, but they have not yet learned enough about how to use computers in training. During the implementation of the program, access to the Internet, the use of information technology in practice, the use of a wider knowledge base. Students and teachers were provided with assistance in making more effective use of this technology.

The program covered topics to be used in the teaching of various subjects. For example, in Life Skills classes, students learned about the Earth's vegetation, seasonal changes in temperature, temperature monitoring, and the reasons why it is necessary to expect an ecological culture in the family, within the school, and in public places. They followed the experiences of their peers by reading online materials about them. Water circulation, protection of water basins, water saving, etc. Such topics showed them a more conscious, responsible and planned approach to issues such as not only water, but also where and how to get food in general, their production and savings.

Problems such as calculations in mathematics lessons, construction of problems on the basis of real-life events, finding answers to difficult problems through games were solved with the help of computers. To develop reading skills, students learned not only books but also e-textbooks with the help of both visual and auditory organs. In the field of fine arts, students had the opportunity to look at more vivid, large-scale drawings and handicrafts, such as landscapes and still life.

As we implemented the program, training in data collection and processing had to be gradually made more difficult. When collecting empirical data, we used appropriate methods in the learning process, with the main goal being the transition of students from passive to active learning. We summarized the results. We now present to you the results we have obtained. We replaced the term "excellent" with the term "high" to equate students' academic performance with the concepts used in the assessment of diagnostic test results. This means that the student reads with a grade of " 5 ". The concepts of "good", "sufficient", and "weak" remain the same. Thus, the first indicators in the tables will show the student's academic grades, the second - the results of the "School Anxiety Test", the third - the "Level of mental development in children", the fourth - the "lability of the intellect". We will first follow the results in tables and diagrams based on these indicators.

To make the comparisons more understandable, it will be necessary to determine the same measurement criteria according to the results of each measurement method. Therefore, we must determine the same units according to the scores given in the test results. For example, "excellent", "good", "sufficient" and "poor" grades in academic grades are adjusted as follows: "excellent" - 5 points; "Good" - 4 points; "Enough" - 3 points; "Weak" - 2.5 points. Eyni qayda ilə istifadə etdiyimiz testlərin nəticələri üzrə ortaq meyarlar müəyyənləşdirək.

1. B. Phillips's "School Anxiety Test". This test consists of 58 questions. We used his first the general excitement scale at school. The number of questions is 22. The greater the number of "no" answers to those questions in the key, the lower the level of excitement. Therefore, we will calculate the opposite. For example, if each of the questions from 46 to 58 is answered "no", the student's level of excitement is low.

Examples of questions on the 1st scale.

46. Do you worry about having more homework than other children?

47. When you are asked a lesson, do you want to cry because you can't answer?

48. When you go to bed at night, do you worry about what will happen at school tomorrow?

49. When working on difficult tasks, do you often forget what you used to know well?

50 . Do you feel your hand tremble slightly as you work on assignments?

51. Do you feel nervous when a teacher prepares to give an assignment in class?

52. Are you scared to test your knowledge at school?

53. Do you feel afraid that the teacher will not be able to cope with the assignment?

54. Do you sometimes fall asleep in situations where your classmates can't do it?

55 . When the teacher explains the new material, do you think that your classmates understand the lesson better than you do?

56 . When you come to school, do you worry about the teacher giving you a test?

57 . Do you feel bad when you do your homework?

58. Do you get excited when the teacher calls you to the board?

Let's match the results with academic grades. Thus, on the basis of 4 measurement criteria, we will compare the changes in the mental development of students of III and IV grades after the impact of computer technology. This is how we can characterize the criteria. 
1. Academic grade given by the teacher $-A B$ (academic score).

2. Excitement situation of the student at school - HB (alarm score).

3. The level of mental development of the student in a particular field - EB (mental development score).

4. The student's focus on the given tasks, continuity of attention, stability and determination of the intellect - LB (intelligence resolution score).

According to the results of the third grade, in the initial and final diagnostics of academic indicators, the indicators rose to the level of 3 people. This happened at the expense of well-educated students. The weak level of anxiety in 5 people rose to 11 people. That is, their emotional arousal has waned. The high rate of mental develop- ment has risen from 9 to 13 people. The durability of intelligence has increased by 6 people. The indicators of a good level have also changed at the expense of the sufficient level ones. EU 4 people instead of 6 . The index of 2 people has reached a high level. HB - from 7 to 6 people, EB - although not quantitatively changed, there was mobility here as well. 1 person passed to a high level, 1 person passed to a good level. LB increased by two people.

Such were the changes in sufficient indicators. Academic score increased by 3 people. Excitement decreased by 1 person. Mental level increased by 1 person. Lability increased in 3 people.

Dynamics also occurred in weak indicators. Two people have risen from a weak academic level to a sufficient level. Weak levels of anxiety (5 peo-

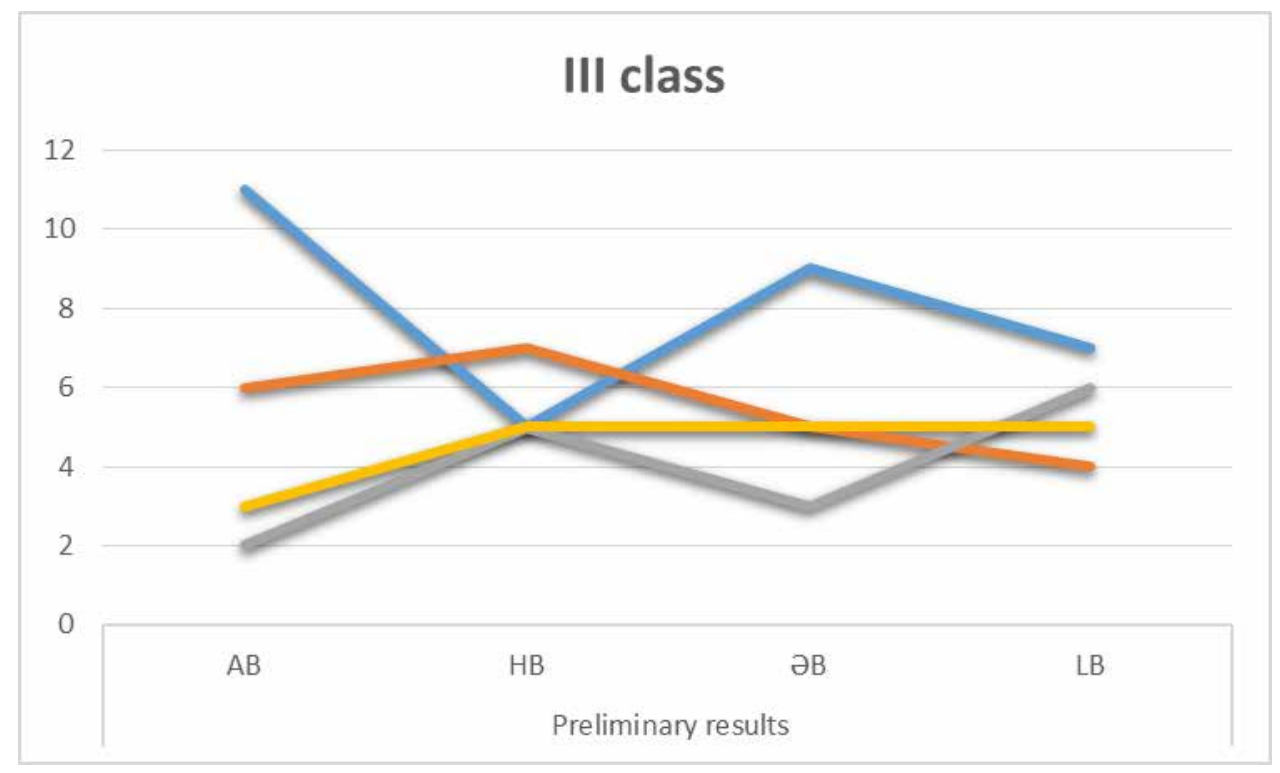

Figure 1. Comparison of initial academic grades and diagnostic results in grade III

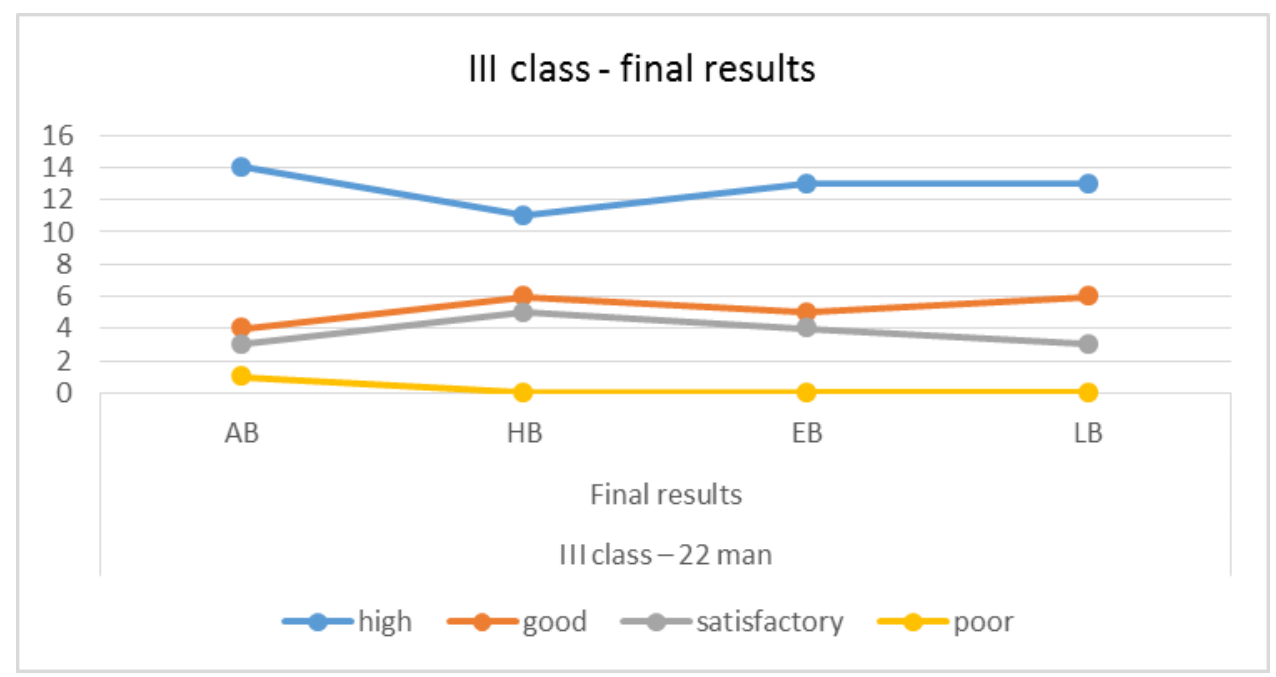

Figure 2. Comparison of diagnostic results with final academic grades in III grade 


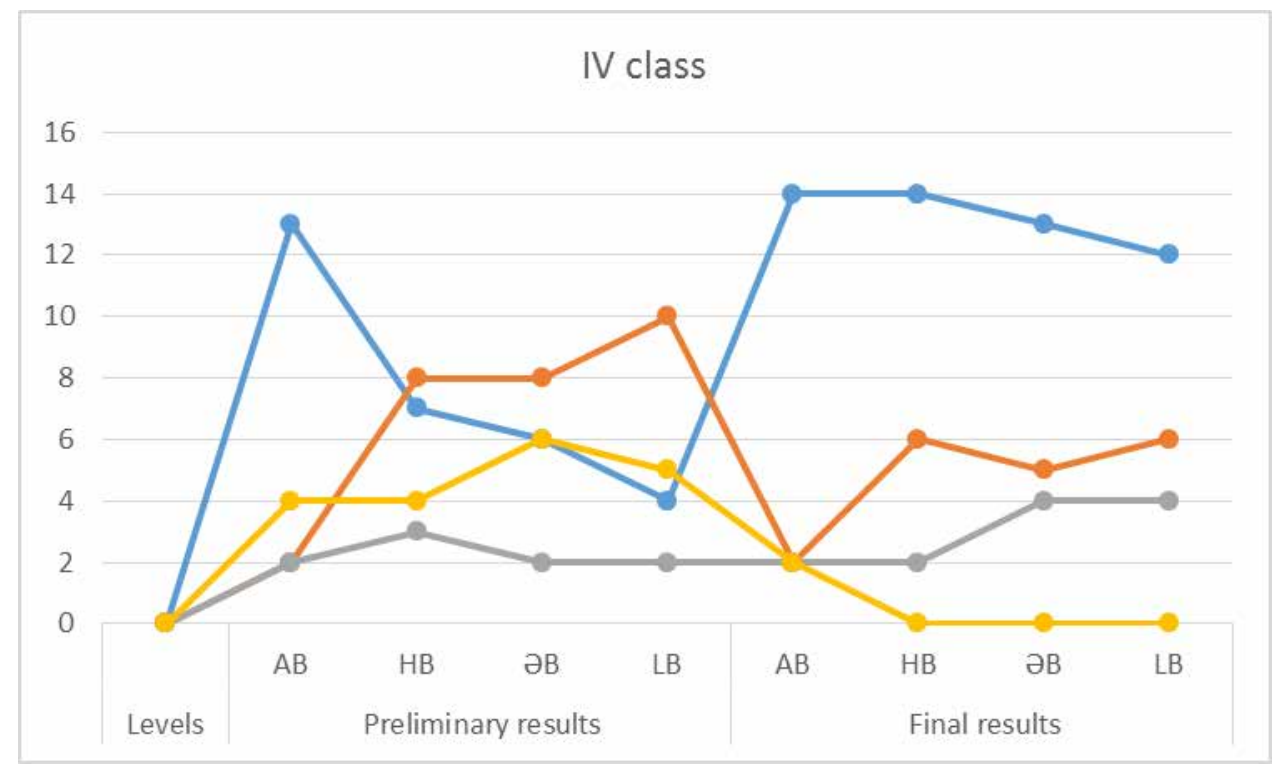

Figure 3. Comparison of initial academic grades and diagnostic results in IV grade

ple), mental development (5 people) and lability (5 people) are high enough .

According to the results of the IV grade, there are differences in the initial and final diagnosis of academic indicators. At the initial level, one person increased. At the emotional level, there was a development in 7 people: the figure rose from 7 to 14 people. The high rate of mental development increased from 6 to 13 people, and the durability of intelligence increased from 4 to 12 people.

According to good indicators, the EU has risen from 2 to 6 people. Excitement weakened from 8 to 6 people. Mental development decreased from 8 to 5 , lability from 10 to 5 . These reductions were due to the transition from good to high levels.

Changes in sufficient indicators remain in the academy in terms of numbers, increasing in terms of progress. Excitement decreased by 1 person. Mental development increased to 2 people, lability to 2 people and reached a good level. Weak changes occurred more in anxiety, mental development, and lability. Academic performance increased by 2 people. In other indicators, it is 4 people. Thus, we see that the computer technologies we apply create positive changes in most areas of mental development of young students. We have studied these changes in their academic assessments, in the areas of excitement, mental development and intellectual resilience, as well as in the field of concentration. The results show that we have reached the goal in accordance with our assumptions.

Conclusions. It means that computer technologies encourage young students to be creative. After studying the impact of computer technology on the psyche of students, we came to the conclusion that they are involved in socially useful activities, such as preparing class schedules, choosing excursion objects, drawing holiday scenarios, young children (sisters, siblings, acquaintances, etc.) are especially interested in computer education when instructed to prepare visual aids, and develop new, original handicrafts in creative activities.

It can also be argued that information technologies have a mixed effect on a student's worldview. But in general, this influence is significant and determines its future outlook. The experience of some foreign countries shows that the lack of supervision and advice of parents and teachers in terms of students' access to information technology can seriously damage the child's physical and mental health, as well as spiritual and moral development.

\section{REFERENCES}

1. Nəzərov A.M. Müasir təlim texnologiyaları. Dərs vəsaiti. Bakı : ADPU-nəşriyyatı, 2012. 103 s.

2. Абасов 3.А. Педагогические технологии и инновации в учебной деятельности школьников. Школьные технологии, 2002, № 5, с. 56-61.

3. Артемова В.В. Дидактические условия обучения младших школьников естествознанию средствами компьютерных технологий. Дисс...канд. психол. наук. Екатеринбург : 2007, 196 с.

4. Утицких Е.В. Применение компьютерных технологий в образовании младших школьников. Курск: Курский институт непрерывного профессионального образования, 2014, 60 с.

5. Целебеева С.М., Прончев Г.Б. К вопросу об использовании информационных компьютерных технологий в начальной школе. Проблемы и перспективы развития образования: материалы II Междунар. науч. конфь. (г. Пермь, май 2012 г.). Пермь : Меркурий, 2012, с. 187-189 
6. Могилева В.Н. Влияние компьютеризации учебной деятельности на формирование мышления учащихся : дисс...канд. психол. наук. Воронеж : 2001, 196 с.

7. Огородников Е.В. Метод параллельных циклов в инорормационных технологиях : монографрия. Москва : МГПУ, 2006, 77 с.

8. Павлова И.М. Формирование готовности младших школьников к проектной деятельности с исполь- зованием компьютерных инсрормационных технологий : дисс...канд. педагог. наук. Москва : 2007, 277 с.

9. Сухойванова Л.В. Использование компьютера в работе с детьми младшего школьного возраста. URL: https://nsportal.ru/nachalnaya-shkola/informatika/

10. Филлипс Б.Н. Тест школьной тревожности Филлипса. Москва : Когито-Центр, 2007. URL: http://lib.mgppu.ru/ 